\title{
Culture in Economics
}

\author{
Shahzavar Karimzadi \\ Hertfordshire Business School, University of Hertfordshire, United Kingdom
}

Copyright $(2019$ by authors, all rights reserved. Authors agree that this article remains permanently open access under the terms of the Creative Commons Attribution License 4.0 International License

\begin{abstract}
It is a self-evident fact that there cannot be a human society without culture. The necessity of culture to humans is imperative. Culture in its most basic sense fulfills and harnesses the obligations of communal cohabitation. Equally imperative is the fact that culture is not an ad hoc construction of any one individual. What is manifestly obvious is that culture is a reality. On this matter, we can draw a definite conclusion. Humans by their nature are social animals and therefore the survival of human beings, by necessity, will depend on living in groups. Leading a completely secluded life is not sustainable. From their very origin, people have lived in various forms of society. In turn, human society is a whole - composed of many interconnected parts. But what is the bond that joins the various parts into one united whole? In this paper, it will be argued that the biosphere of any society is culture. That is the all-inclusive common denominator and invisible glue that interlinks all the parts as the whole. From this perspective culture is dispensable and its function is more profound, organic and dynamic than perceived in economics. The paper examines how different schools of thought in economics view culture in light of the aforementioned standpoint.
\end{abstract}

Keywords Culture, Economy, Economic Process, Ontological Individualism, Neoclassical Economics, Historical School, Invisible Hand, Relations of Production and the Transitivity of Contingency

\section{Introduction}

Culture represents a crucial element in the essential nature of people. The necessity of culture to humans is imperative. Culture fulfills and harnesses the obligations of communal cohabitation. Subject to this qualification it is rather short-sighted to consider culture as an ad hoc creation of a single individual. Culture is a reality that we cannot dispense with or deny. As it is real there can be no doubt that it must have a history and a formal origin. On this matter, we can draw a definite conclusion because humans by their nature are social animals.
Humans have an essentially common coexistence. Their survival depends on living in groups. They have always lived in one sort of society or another. Leading completely isolated lives is unfeasible. The need for a group lies at the heart of human identity. The absence of groups or collective structures would lead to the extinction of our species. Thus, mankind by necessity is compelled to possess a social life. For their survival, they are compelled to interact and cooperate. The origin and history of culture are vital facets of this process. From the foregoing, we can extrapolate that culture is an inextricable prerequisite of communal existence. The recognition and disentangling of this necessity is central to our comprehension of culture in a society.

If, indeed, it were true that all aspects of life hinged on culture - according to this postulate the economy would be one of these aspects. One can reach a firm supposition if we extend this argument to its logical conclusion. That is, contrary to the prevalent view in economics, culture is neither irrelevant nor a secondary matter of society. Culture cannot be discounted totally. Nor can it be regarded as a marginalized issue.

The scope of culture is very wide and diverse. Culture in economics is restricted from nothing to partially relevant. Moreover, it is circumscribed within the artificial boundaries of states. On this matter, care needs to be taken. Many boundaries are colonial constructions. They consist of parts of multiple nations. In such cases, culture only has a symbolic importance. Whereas, culture is far more. Culture is one seminal element among all fundamental essentials of a human society. It is the biosphere and invisible adhesive that holds all parts of the society together.

The object of this paper is to present an alternative account of culture to that of the conventional economic theory. More particularly, it refutes the supposition of an economy devoid of culture. From this perspective, culture is not just an appendage of the economy, technology, law, government, ideas or religion. Rather it is an all-encompassing organic process that can only be understood holistically in the context of a society in its course of unremitting motion.

Broadly speaking, there are two approaches in the 
economics discipline regarding the relationship between culture and economy. One practically overlooks culture and the other diminishes it to a mere peripheral constituent of the economy. The contribution of this inquiry is threefold: firstly, the paper surveys and takes a detailed look at economic literature and tries to elucidate views of economists on culture from different schools of thought in economics. Secondly, counter to the current body of knowledge in economics, this study considers culture as the most vital bond that links and unites all parts of society. The economy is just one part of society. Third, this paper postulates a different taxonomy of culture. A culture that is rational, open, humane, democratic, progressive and dynamic and a culture that is hostile to the aforementioned attributes. This research has adopted an interdisciplinary research framework. It has drawn from trans-disciplinary scholarly studies, most specifically from economics, cultural studies and political science. This paper is a contribution to the heterodox schools of economic thought.

The first part of this paper will provide a summary background to the origin and development of the concept of culture drawn from different research disciplines. In the second part, we shall look at how culture is perceived in economics. In the third and fourth parts, we shall explore the necessity of culture and the prerequisites upon which a culture is formed. The last two parts of the paper will relate to taxonomy and the role of culture in stitching the various parts to one another within a human society. These two parts will explain and examine the essential elements of a culture. In these parts including the concluding section, we shall discuss what constitutes a whole and examine the relationship of the whole to its parts in a human society. We shall argue that culture is the connective that joins different parts of a society. We take culture as the string that ties the different parts of a society to create a whole and touch on some implications of this inference.

\section{Lingering Contention}

In 1993 the UN established the World Commission on Culture and Development. The UN held a general conference on 8 October 1993 in Paris for this purpose. In the summary of the twenty-seventh session information document [1], 27c/INF.11 - 8 October 1993, we find a significant shift of position in respect to the role of culture in economic development. The document reads "successful development ... demonstrates the value of approaches that aim to combine the specific resources of each culture more effectively with economic, scientific and technical progress. Genuine development can only be built on the basis of culture, which is its source, its mainspring, and its ultimate goal." In Stockholm, April 1998, the representatives of about 150 governments endorsed the same sentiment. So did the World Bank in 1999 [2].

The concept of culture is one of the most ill-fated terms when it comes to its definition. There have been longstanding debates on the issue. These discussions have concluded with no firm sense of resolution. The ideal has yet to be realized. On some aspects of culture, however, there is full agreement. Culture is perceived to be diverse and transitory. The quandary is that everyone appears to have a perspective in relation to the meaning of culture. However, no one knows what it actually is. Throsby argues that culture is used "in a variety of senses in everyday use but without tangible or generally agreed core meaning" [3].

Like all terms, culture has its own history. Marcus Tullius Cicero (106-43 BC) first used the term in his work Tusculanae Disputationes. The culture here is seen as intellectual and philosophical cultivation of mind [4]. In the Middle Ages culture was brought under the domain of religion. The Renaissance revived it and circumscribed it to one's moral and intellectual development. The age of enlightenment broadened its meaning to encompass the whole of society. They also, consistent with the fashion of the time, classified culture into two categories, the degenerative and the progressive cultures [5].

One fact about culture outshines others. It means different things to different writers. To Beugelsdijk and Maseland culture is "something like a society's traditions, its values, norms and beliefs ... [it] refers to artistic activity, its products and the historical heritage of a society" [6]. Soon after giving this definition the authors concede defeat by confessing that their definition by no means is conclusive. To Ostwald culture is "that which distinguishes men from animals" [7]. For Herskovits, it is "the man-made part of the environment" [8]. Inglehart asserts that it varies "from one society to another" [9].

Kroeber and Kluckhohn refer to it as a "comprehensive totality" [10]. Likewise, Taylor says it is "that complex whole which includes knowledge, belief, art, morals, law, custom, and any other capabilities and habits acquired by man as a member of society" [11]. For Boas, it "embraces all the manifestations of social habits of community" [12]. To Malinowski, it is "composed of partly autonomous, partly co-ordinated institutions" [13].

To many anthropologists, culture is a system of distinct meanings. Geertz states that culture is a "historically transmitted pattern of meanings embodied in symbols, a system of inherited conceptions expressed in symbolic forms by means of which men communicate, perpetuate, and develop their knowledge about and attitudes towards life" [14]. Culture is also said to be about distinction. Beugelsdijk and Maseland say culture "has to do with how groups differ from one another" [15]. To the cross-cultural psychologist, G. Hofstede, culture is "the collective programming of the mind, which distinguishes the members of one group humans from another [16]. Wallis describes it as "the artificial objects, institutions, and modes of life or of thought which are not peculiarly individual but which characterise a group" [17]. It is also termed as "what really binds men together" [18]. 
DiMaggio identifies culture as "norms that mandate action that is not in one's own interest or proscribed behaviour" [19].

Linton equates it with "the total way of life of any society" [20]. To R. Williams culture is "a state or process of human perfection, in terms of certain absolute or universal values" [21]. In Johnson's view culture is "the whole complex of knowledge and beliefs and attitudes and practices which are embodied in the society, and in its social, political and economic arrangements" [22]. N. Garnham boils it down to mere symbolism, to "the production and circulation of symbolic meaning" [23]. R. Robertson condenses it to what "individuals, groups and societies produce and acquire in order to function effectively" [24].

In some cases, the definition offered fits almost any scenario. One example of this is J. Friedman's definition. The culture here is described as "distinctive about others" [25]. An assertion of this kind can be a plea for anything anywhere, which adds nothing to our understanding. Edward B. Tylor is of opinion that culture is inclusive and is synonymous with civilization. Culture is "the complex whole which includes knowledge, belief, art, morals, law, custom, and any other capabilities and habits acquired by man as a member of society" [26]. In C. Kluckhohn view culture is made up of "traditional ideas and especially their attached values" [27]. Margaret Mead contends that it is "an abstraction from the body of learned behaviour which a group of people share the same tradition" [28]. In J. Frow's interpretation, it covers "the whole range of practices and representations through which a social group's reality (or realities) is constructed and maintained" [29].

P. Lederach finds culture "rooted in the shared knowledge and schemes created and used by a set of people for perceiving, interpreting, expressing, and responding to the social realities around us" [30]. T. Eagleton associates it to "the complex of values, customs, beliefs and practices which constitute the way of life of a specific group" [31]. F. Matarasso limits it to "the expression of human values" [32].

Even from this short sample, we can see the wide range of views expressed about the meaning of culture. The fact is all definitions presented here bear some truth about culture. But no single definition is or can be conclusive. These are educated conjectures that are only partially true. In their study, Kroeber and Kluckhohn, have collected 160 different definitions of culture but found none of them acceptable [33].

\section{Culture and Economists}

Culture is a reality. There is no disagreement, on this issue, among economists. The disagreement is related to whether culture affects the economy or not and to what extent. The degree to which culture is made relevant or irrelevant varies from being significant to negligible. Overall, there are two major tendencies in economics in relation to culture. Mainstream economics, by and large, perceive culture as a somewhat ambiguous area that cannot be studied scientifically. Those who find a place for culture are either ambivalent on its bearing or see it as an auxiliary part. Even economists from diverse ideological backgrounds who consider culture as relevant - would play down its significance. They would reduce it to an accessory constituent of either economy, technology, politics, religion or ideas.

Before we probe deeper into the subject of our inquiry we give a brief account of what economists say about culture. Adam Smith (1723-90) initiated modern economics. In his book; An Inquiry into the Nature and Causes of the Wealth of Nations (1776), he laid the foundation of modern economics. Smith outlined many of his ideas in his first book, The Theory of Moral Sentiments (1759). In both books, Smith is mindful of a cultural and moral context in which economic activities are realized. In The Moral Sentiments, Smith looks at the motives that instigate spontaneous cooperation among individuals in a society. Chiefly, how the tie and solidarity between individuals are formed. For Smith, it is by the means of human ethics and culture [34].

In The Theory of Moral Sentiment, Smiths maintains that "many men behave very decently, and through the whole of their lives avoid any considerable degree of blame, who yet, perhaps, never felt the sentiment upon the propriety of which we found our approbation of their conduct, but acted merely from a regard to what they saw were the established rules of behaviour" [35]. For the purpose of this paper, the emphasis here should be on the pre-established "rules of behaviour." These rules are nothing other than social and historical customs.

In the Wealth of Nations, Smith demonstrates the significance of culture in relation to the economy when he discusses consumable goods. He divides commodities into necessary and luxury commodities and says "by necessaries I understand, not only the commodities which are indispensably necessary for the support of life, but whatever the custom of the country renders it indecent for creditable people, even the lowest order, to be without" [36]. Besides, these specifics, Smith considers the economy a social process and economic engagements as social actions. Such undertakings cannot be accomplished in the absence of any legal, moral and cultural context. Smith has skilfully illustrated this process in his example of the pin factory as a cooperative course of action. We find numerous individuals working on multiple tasks in a social setting. Smith introduced the concept of an invisible hand into his economic system because of this intricate interaction between different parts of society. The concept is not exclusive to economics. The spontaneous collaboration and coordination of innumerable opposite interest groups cannot rest solely on economics. 
Another celebrated economist and political philosopher in the tradition of classical economics was J. S. Mill (1806-1873). One place that he brings culture directly to the view of the reader is in his distinction between production and distribution of wealth. The argument goes as follows. Production is subject to the laws of nature whereas distribution is not. Production operates in accordance with universal laws and distribution does not. Mill postulates that distribution "depends on the laws and customs of society" [37].

The Marginalist Revolution in the 1870 s ended the dominance of classical economics. The charge against classical economics was that they were not dealing with clear-cut facts. Their ideas and findings were unscientific. Two factors have contributed to this debate. In the first instance, the root of the contention goes back to Jeremy Bentham's (1748-1832) utilitarian philosophy. In the first chapter of An Introduction to the Principles of Morals and Legislation (1780), Bentham laid the foundation of his philosophy in which individuals are motivated by the desire to maximize pleasure and to minimize pain. Bentham purports that "nature has placed mankind under the governance of two sovereign masters, pain and pleasure. It is for them alone to point out what we ought to do, as well as to determine what we shall do. On one hand the standard of right and wrong, on the other the chain of causes and effects" [38]. From this maxim, Bentham deduces that "the community is a fictitious body" [39].

Discarding society from the equation has left a long-lasting impact on the core tenets of the prevailing economic theory. This is particularly true with regard to the role of culture in the economy. We can identify at least three stimulants that have widened the gap between economics and culture. All three are products of the 'Age of Enlightenment.' This was the age in which the trend of classification and standardization were in vogue. This trend also spread to culture. In due course two types of culture were identified, the progressive and degenerative cultures. This was an expedient plea for the expansionist imperial states in Europe to colonize nations deemed 'uncivilized.'

This was the dawn of modern science with its far-reaching implications. One being the craze of the imitating natural sciences in the social sphere [40]. The power of scientific discoveries and inventions was epidemic. In social sciences, it was economics that showed the greatest vulnerability. Subsequently, equating application of mathematical and geometrical language to science. The third catalyst was the emphasis on individualism. It was initiated from the step taken to release individuals from the yoke of blind faith and empty traditions. In the end, they elevated it to an end in itself. The advocates of the age of enlightenment professed that each individual is born free and endowed with the ability to reason. So the priority was given to individuals at the expense of society, state, institutions, and religion. Individuals are said to be equal. From this argument developed the concept that individuals should be self-reliant, independent and self-determined. The positive manifestation of this outlook was instituting freedom of thought and personal autonomy in conducting one's reasoning, morality and living on one's own free will.

William Stanley Jevon (1835-82), Carl Menger (1840-1921) and Leon Walras (1834-1910) founded the Marginalist school. All three authors published their books independently in the $1870 \mathrm{~s}$. These books contained the core ideas of the school. Jevons and Menger both published their works; Theory of Political Economy and Principles of Economics respectively in 1871 . Walras book, Elements of Pure Economics, was published in 1874. One of the defining aspects of these books was the integration of Bentham's utilitarian philosophy into economics. The other aspect, except in Menger's book, is the application of mathematics in their works. Jevons equates the feelings of pleasure and pain with the forces of utility and disutility. He remarks that "value depends entirely upon utility [and] pleasure and pain are ... the ultimate objects of the calculus of economics" [41]. He goes on to say that the problem of economics is "to maximize pleasure" [42]. Jevons is convinced that to pass from pre-scientific economics to scientific economics, economics "must be a mathematical science" [43].

It is no wonder that entrenched at the core of the school's fixed doctrines is the idea of the rational individual. The most forthright exponent of this view was Menger. Instead of an application of mathematics, his methodology is based on ontological individualism. The thrust of Menger's theory is the close likeness between social and natural sciences. Social sciences can be as reliable as natural sciences on the condition that the social phenomenon is reduced to its simplest element i.e. to an individual. The reasoning behind this is that an individual's action is an ontological necessity. The 'economic man' is the indivisible rational unit [44]. It is the base and the essence of any social and economic phenomenon. Implicit in this idea is getting individuals off human associations, communities, classes, nations, and cultures.

One implication of this shift of emphasis was to discard the classical labour theory of value. For classical economists, in particular, Marx, the value of commodities is ultimately determined by the amount of labour embodied in the commodities [45]. Therefore, the formation of value is a social process. The Marginalist school saw it as a personal matter, a subjective evaluation. The value of a good is determined by the subjective degree of usefulness of a good that each person attaches to it.

At this junction, mathematics enters into the scene as a convenient method of calculating utility. Leon Walras, in defence of application of mathematics, wrote that "thanks to this mass, so defined, the mathematicians who elaborated celestial mechanics have been able to demonstrate that: 'the celestial bodies attract one another in direct proportion to their mass and in inverse proportion 
to the square of their distance', and have explained astronomical phenomena and established mathematical astronomy. Thanks to rarete, defined in the same way, I have been able to demonstrate that: 'goods tend to be exchanged one against the other in inverse proportion to their rarete' and have explained the principal economic phenomenon and sketched out a pure mathematical political economy" [46].

Given the assumption that individuals are rational and calculating, all three founders of the Marginalist school maintained that economic agents make their decisions either to buy or sell at the margin. All three authors used utility as given. Jevons and Walras used mathematics to demonstrate this, whereas Menger used an arithmetic table to explain his theory [47].

The Marginalist school evolved into the neoclassical school [48]. Mirowski states "the progenitors of neoclassical economic theory boldly copied the reigning physical theories in the 1870s. The further one digs, the greater the realization that those neoclassicals did not imitate physics in a desultory or superficial manner; no, they copied their models mostly term for term and symbol for symbol, and said so" [49].

One school of thought in economics that opposed this stance was the German historical school. Their point of reference is nationhood [50]. Each nation has a distinctive and unique culture and history. The economy is only an integral part of a nation's culture and history. We find this stance in the writings of Wilhelm Roscher (1817-1894), Bruno Hildebrand (1812-78), Karl Knies (1821-98) and Gustave Von Schmoller (1838-1917).

Implicit in the works of these authors is the premise that the economy is one part of a greater arrangement. One cannot understand the economy if it is eliminated from this totality. The founders of the school; Roscher, Hildebrand and Knies emphasise on studying the whole social order and then tracing economic activities, decisions and motivation within this overall order. After all, it is the place and time that makes the economy. Economic acts and conducts stem essentially from the instincts of survival and morality. Economics is essentially an ethico-political discipline. Schmoller considers culture central to the understanding of human societies. For this purpose, we just need to unearth cultural trends by means of extensive historical study. Roscher termed this method as a 'historical-physiological' method. According to this method, the study of the economy should not commence from the best possible state of affairs but from the actual state of affairs as they develop and change in a given nation.

Possibly the most earnest adherent of the historical school was Max Weber (1864-1920). The school certainly had a profound impact on his economic ideas. For Weber, making the best economic decisions is not limited to the margins and maximization of utility and profit. In his seminal book, The Protestant Ethic and the Ethic of capitalism (1905), Weber relates the economic transition of northern Europe to Protestant culture and their work ethics [51].

The school that adopted the historical approach is the Institutional School of Economics. Thorstein Veblen (1858 - 1929), the founder of the school, published a number of ground-breaking books where he put culture at the forefront of his criticisms of orthodox economics. He objects to a value-free economic theory. Orthodox economic theory, Veblen argued, is pre-Darwinian and teleological. It seeks an end that is in perpetual harmony and equilibrium [52]. To Veblen economics is more than allocating scarce resources among alternative uses. Economic decisions and activities do not occur outside historical, cultural and institutional contexts. Culture is pivotal in forming institutions and institutions are habits of thought that prevail in time and place [53].

Veblen defines institutions as "an outgrowth of habit. The growth of culture is a cumulative sequence of habitation, and the way and means of it are the habitual response of human nature to exigencies that vary incontinently, cumulatively, but with something of a consistent sequence in the cumulative variations that so go forward-incontinently, because each new move creates a new situation which induces a further new variation in the habitual manner of response" [54]. One cannot think of individuals outside a cultural boundary. Individuals are born in a specific culture and follow the established pattern of behaviour. The crystallisation of these patterns are the present institutions. Veblen says "not only is the individual's conduct hedged about and directed by his habitual relations to his fellows in the group, but these relations, being of an institutional character, vary as the institutional scheme varies" [55].

Other members of the Institutional School, for instance, John R. Commons $(1862-1945)$, laid more emphasis on the critical role of law in the economy. To Commons, the task of Institutional Economics should be "to coordinate the theories of law and economics" [56]. He saw economic transactions as social processes that involve conflicts - and disputes and solutions at the mercy of culture [57]. Institutions are crucial because they direct and shape our collective actions. Our collective actions, in turn, determine an individual action but it is also a force for safeguarding individual liberty. Commons closes his argument by saying that it will free individuals "from coercion, duress, discrimination, or unfair competition, by means of restraints placed on other individuals. And collective action is more than restraint and liberation of individual action - it is an expansion of the will of the individual far beyond what he can do by his own puny acts" [58]. Schmoller is much more explicit on the question of culture. He describes culture as a social process and economics as a part of this process [59]. J. K. Galbraith encapsulates this process by saying that "there is much of the past that is in the present, so also there is much of the 
present that will be in the future" [60].

Another unconventional school that has much in common with the institutional school is the Swedish School of Economics. One critic whose name is associated most with this school is Gunnar Myrdal (1898-1987). Myrdal's refutation of neoclassical theory has three dimensions. In all three areas, Myrdal maintains that orthodox economics has omitted culture from its model. These are in the areas of methodology, development and economic growth. Myrdal censures the neoclassical methodology as "naïve empiricism." A practice that is at odds with the reality and lacks any logical foundation. The standard neoclassical analysis does not account for the subtle changes that take place constantly in economic conditions. Myrdal adds "Facts do not organise themselves into concepts and theories just by being looked at; indeed, except within the framework of concepts and theories, there are no scientific facts but only chaos" [61].

Thus, to understand any economic process i.e. economic development, Myrdal proceeds "history and politics, theories and ideologies, economic structures and levels, social stratification, agriculture and industry, population developments, health and education, and so on, must be studied not in isolation but in their mutual relationship" [62]. It is the study of these mutual relations that form the culture of each period in the course of the history of any nation. Myrdal regards long-run economic growth as the central subject of economic analysis. An area that mainstream economics has failed to provide a workable explanation, due mainly to their concept of equilibrium. All parts of a society do not change and adjust uniformly. The methodology that is best suited to the study of a society should be a methodology that embraces all relevant factors holistically i.e. the methodology of cumulative causation.

To sum up, two trends have emerged in economics with respect to the issue of culture. The neoclassical economics represents one of them. The primary lever here is the rational individual. Individuals conduct their economic activities on the basis of computing their pain and pleasure. Hidden in this trend is the implicit desertion of society. The other trend acknowledges society as real and relevant but views culture as a subset of different parts of society. The economy is only one among those parts.

\section{Indispensable or Inconsequential}

Is culture a necessity? This question calls for further clarification. Is it encoded in our DNA? Is it acquired in a specific social setting? If the social setting is the only prerequisite for the formation of a culture then some animals also form and live in some sort of social setting. The question is why they do not have a culture. The answer to this question is said to be because they follow their natural instinct. However, humans cannot survive just on their instincts. To compensate for this disadvantage instead they rely on their faculty of intellect to reason.

Manfred Max-Neef divides fundamental human needs into two broad groups. In the first instance, there are biological needs such as food, shelter, and clothes. These are classified as universal subsistence needs. In the other group need such as protection, affection, understanding, participation, leisure, creation, identity and freedom. These needs are not biological [63]. It goes without saying that irrespective of what culture, belief, values a person upholds, one cannot live without his or her biological needs. At the same time all human needs listed in Max-Neef matrix, biological and non-biological, are meaningful within a given cultural context.

Formation of a culture is also said to be out of necessity for the reason that any society is destined to form some kind of order, cooperation, and communication. Otherwise, it would not last long. Culture is the venue, it is argued, by means of which these shared interactions are materialized. These activities are not instinctive and are only acquired during the course of human relations with each other in a society [64].

On the other hand, human infants are so dependent that they cannot survive on their own. If that is so, is it not a sufficient reason to assume that culture is embedded in human nature? That is to say, it is the human constitution that necessitates culture. By the virtue of the fact that the human race is naturally a social animal then, as a consequence, culture must be an instinctive human behaviour. One thing that we can say on this matter is that the necessity of human culture is primarily due to their social life if it is not encoded in one's DNA. Nonetheless, we are, to a degree, guided by our instinct. This is where we can draw a vital distinction, the distinction between human biology and human social life. One can stay alive without social life but not in the absence of one's biological needs. That being said we also know that without culture "social life would not be possible" and culture is a necessity because of the dependency of humans on each other to pursue their common goals [65].

The founders of modern sociology, K. Marx, M. Webber, and E. Durkheim, placed culture at the centre of their studies of human behaviours and actions. E. Durkheim (1858-1917) reminds us that individuals create societies. As they form societies, they experience two realities. The first reality is about individuals and the second is about society. He underscores his distinction by attributing a separate reality to society, a reality that is external to each individual. Durkheim points out that with the formation of a society there will be "a category of facts with very distinctive characteristics: it consists ways of acting, thinking and feeling, external to the individual, and endowed with a power of coercion, by reason of which they control him" [66].

Culture transcends individuals. Individuals are the creators of social solidarity, cooperation, reciprocity, mutual obligation, conflict, disorder, beliefs, and moral 
codes. Culture is the totality of all these forces. Durkheim defines culture as the collective conscience that constrains an individual's actions. It is worth mentioning here that for Durkheim the collective conscience and an individual's conscience are not the same. As individuals enter a society they experience a collective conscience. Each person then discovers his or her dependency on the collective conscience. This is how they learn to practice their social duties and obligations. In the event that there was no collective conscience independently of the individual conscience and that the only force of action was self-interest, Durkheim argues that society would not be possible. Durkheim states that "where interest is the only ruling force each individual finds himself in a state of war with every other" [67].

Along with a similar line Max Weber (1864-1920) conscripts human beings under the category of cultured species. However, there are two overlapping sides to his notion of culture, which are linked to his classification of sciences into 'the cultural sciences' and the 'natural sciences' [68]. Weber describes culture as "a finite segment of the meaningless infinity of the world processes, a segment on which human beings confer meaning and significance" [69]. So human actions can only be understood within a given meaning or sense. Take exchange for example. Weber remarks that "the essence of what happens [in this act] is constituted by the meaning which the two parties ascribe to their observable behaviour" [70].

The interactions and transactions are much more than a pure objective act. He carries on to say "the quality of an event as the social-economic event is not something which it possesses objectively. It is rather conditioned by the orientation of our cognitive interest, as it arises from the specific cultural significance which we attribute to the particular event in the given case" [71]. While resting much emphasis on the "value-concept" of culture, he adds that "empirical reality becomes 'culture' to us because and insofar as we relate it to value ideas. It includes those segments and only those segments of reality which have become significant to us because of this value-relevance" [72].

Equally, culture is pivotal to Marx's analysis of social relations of production. Marx's world is the world of concrete reality. This is how he spoke of it in the preface to his Critique of Political Economy: "in the social production of their existence, men inevitably enter into definite relations, which are independent of their will, namely relations of production appropriate to a given state in the development of their material forces of production. The totality of these relations of production constitutes the economic structure of society, the real foundation, on which arises a legal and political superstructure and to which correspond definite forms of social consciousness. The mode of production of material life conditions the general process of social, political and intellectual life. It is not the consciousness of men that determine their existence, but their social existence that determines their consciousness" [73].

On the whole, there are two channels through which culture enters into Marx's economic theory. The first one is through his conception of humanity. To Marx, human species are social beings. In corroboration of this assertion, he reasons that "society does not consist of individuals, but expresses the sum of inter-relations, the relations within which these individuals stand" [74]. These relations necessitate a complex network of ties that coordinate the values, interests, property ownership, ideals, standards, morals, status, political power, legal obligations, expectations, and orders.

For Marx culture also is an offshoot of a class struggle. In the Communist Manifesto, Marx and Engels declare that "the history of all hitherto existing society is the history of the class struggle" [75]. Nothing can escape this conflict of interest. In a sense culture is one element in this battle. This is due to incompatibility of the interests of the opposing classes in the class-based modes of production [76].

One peripheral reading of culture is to be found in Hobbes's interpretation of human nature. Thomas Hobbes (1588-1679) articulated his bleak image of human nature in his two major books, De Cive (1642) and Leviathan (1651). His depiction of human nature is superseded in his two suppositions about human knowledge and history. a) Hobbes questions our power of reasoning and regards it as inadequate since we rely on language to acquire knowledge. $\mathrm{He}$ describes language as an imprecise tool of communication. But our actions are conveyed through a language. So our actions and reality may fragment when we use this medium. That may result in doing things that are wrong and dangerous. b) Hobbes divides history into two periods. In the first period, there is no political authority and people lived in the "natural condition of mankind." The prevailing authority during this period is the authority of a mother to her child, which is the only natural authority. However, the state of nature is undesirable since people live in constant fear, competition, warfare, violence, insecurity, bloodshed and danger.

Hobbes alleges that the state of nature marks the "beginning of time." During this time "there is no place for industry; because the fruit thereof is uncertain: and consequently no culture of the earth; ... and the life of man, solitary, poor, nasty, brutish, and short" [77]. From this portrayal of the state of nature, Hobbes surmises that human nature, being as it is under the state of nature, requires an authority to impose an order for the sake of a perpetuation of the human race. Unless there is an authority to rule we will have no culture and be living in a state of constant war. The best outcome of living with no authority will be a situation where "the wickedness of bad men also compels good men to recourse, for their own protection, to the virtues of war, which are violent and fraud" [78]. 


\section{Cultural Species by Necessity}

For any human being to live he or she needs food, water and shelter and so on. These very basic requirements of existence drive individuals to engage and interact with each other and with their natural environment. All the same, the provision of the most basic requirements of life is possible for one person even if she or he embraces a solitary life in an uninhabited island. Leading an insular life, cut off from others, in a remote location is possible but it is certainly not a viable method of preserving the human race. There is no necessity for a culture in an economic setting that is solitary and totally segregated. The most elementary building blocks of any economic relations and production can be carried out even by a withdrawn misanthropic person embracing a lonely existence. That being said, this type of living requires no language and culture. Many thinkers in antiquity were mindful of this fact and acknowledged it in their literature. On this issue, no ancient thinker is more outspoken than the Greek philosopher, Aristotle (384-322 BC).

We often hear that humankind by their nature is best defined as ' social animals.' In support of this assertion, the erudite, immediately refer to Aristotle. In book one of the Politics, it was said that Aristotle coined the phrase "man is by nature a political animal" [79]. However, this is not what Aristotle actually said. The phrase "man is by nature a social animal" is what Thomas Aquinas (1225-74) attributed to Aristotle. Nowhere in Aristotle's original Greek text can we find this exact phrase [80].

What is very plain in Aristotle's message is that the human race cannot survive in isolation because "an individual is not full-self-sufficient" [81]. Implicit in this saying is the central premise that human beings by nature are social animals. That proposition in itself is uncontended. In general, it is presumed as a self-evident truth. If humans are social animals and they can only survive in forming societies then the formation of a human society is a necessity. That is in depriving them of a society this would, in consequence, be tantamount to depriving them of a continuous existence. Formation of human societies, therefore, is not a matter of choice but a requirement. Thus, by their very nature, human beings are social animals and being social is indispensable to their survival.

After all, human infants are helpless. They are completely dependent on others to live, grow and learn. Their survival is wholly at the mercy of their parents and the community. They are defenceless and cannot fend for themselves for a long time. If left alone they cannot survive. In short, there are many other aspects of being human that will not be utilised and fulfilled in adopting a solitary life. Therefore, developing social units in its most basic form is a natural necessity for humankind. As well as this, the human species have a range of embedded characteristics, qualities, attributes, propensities, capacities, and abilities that can neither be discerned nor utilised or fulfilled if they live in isolation. These are the ability to think, imagine, language, to inquire, to invent and discover, to learn and to be moral, to be creative and to work, to write and to transform knowledge, to help and much more. These activities cannot be nourished in a solitary life. Their growth is possible if and only if there is a venue for social and cultural interaction between human species.

In addition, infants due to the chronic underdevelopment are not aware of their own self. Discerning one's self equally cannot be recognised by an infant and then nurtured in a solitary environment. Being aware of oneself and conscious of its significance and implications are possible only in a social setting. It is in the interaction of individuals in a social venue, in a shared habitation, that someone's own self can be realised. Given that human infants are not aware of their own self, then this awareness must develop in the later stages of their growth as they enter and interact with others in their given societies. This mode of thought was fostered particularly by an influential American philosopher and sociologist, Charles H. Cooley (1864-1929). Cooley asserted the view that the awareness of self is inextricably linked and manifests itself in the interaction of individuals in a society [82].

The principle of sufficient contingency equally applies to this situation. If a person leads a solitary life is questionable then the human species continued existence is contingent to social life. This being so it follows that living in a society would not be a matter of choice for any individual but a matter of survival of its kind. That is all. Consider this transitivity of contingency for a moment. Unlike necessary truth that depends on repetition, the transitivity of contingency does not replicate itself. In virtue of this insight, we can deduce that a society cannot be the labour of an abrupt construction that comes into being in an instant. A society even in its rudimentary stage is a product of a long process of evolution and development. In the course of its evolution, it accumulates a baggage of values, beliefs, customs, economic and power relationships, institutions, knowledge, skills and experience, legal and moral codes, hates and resentments, art, literature, and music and so on. Collectively, they form the heritage of each society. The spectre of this baggage looms on every new-born baby. It is the contents of this baggage that is pre-set and forced on them which defines and shapes their role in their respective society.

In view of what has been said, it is a shared necessity that has compelled the human species to adopt a cooperative existence and a social life. No human infants can escape from being helpless at birth and from the heritage that is lumbered on him or her at their birth. A baby cannot survive without the care; affection, nutrition, and shelter of their parents nor in the absence of the collective heritage that he or she would encumber from their community. More than that human infants are not just chemical and biological constructions but are also intelligent beings with infinite inborn potential. These potentials are shaped and 
utilised by their heritage and social settings. It is this belonging that shapes their economic relations, their role in society, their attitudes, beliefs, identity, thoughts and emotions, potentials, aspirations, expectations, and desires.

The human race would have been extinct a long time ago had they adopted a solitary and way of life excluding culture. No human solitary existence has ever lasted more than a generation. There may well be cases where a few individuals break free from a society and choose a hermetic life but this is by no means in the absence of a society. It happens within a given social order and the support they receive from that society.

This is true in the case of Daniel Defoe's fictional character, Robinson Crusoe. The grounds for Robinson's success, in assuming a new hostile environment, was due to the skills and knowledge that he had acquired in the society that he was born to, which happened to be the most advanced society of its time. Had he been brought up without society he would not have been able to get to that Island in the first place and probably not have lived long enough to reach adulthood. All individuals who have been discovered living outside of human societies from infancy due to some unfortunate circumstances have been chronically disabled both physically and mentally. Most of them died not long after being taken into care and those who survived have remained disabled for the rest of their lives.

Given what we have said in the foregoing sections, we can safely say that there cannot be a culture, a language or an organised exchange economy if individuals are isolated from society. As humans are social beings, their social co-operation and interactions necessitate the birth of such relations. These activities are symbiotic and inseparable. Their formation is not the outcome of a conscious plan or a design of an individual or conscious planning of groups of individuals. They have emerged spontaneously in line with the formation of human societies. It takes time for any human society to be formed. Time is another indispensable element for a culture to flourish.

\section{Taxonomy of Culture}

Residing in a shared land is accidental. It is not something that an individual can choose when and where he or she is born. Children have no say in this matter. Whoever occupies a piece of land and settled there would be able to decide the culture that their offspring would be brought up in. As these people settle on a given plot of land for considerable periods of time, decades, centuries and in many cases for millennia, they form a nation. One of the most distinctive attributes of any nation is the all-inclusive worldview of their existence. Variation in settlements is largely caused by a variation in the means of adapting to different natural as well as man-made environments. History, mode of existence, art, music, language, moral values and the worldview of people who live in different parts of the world vary in accordance to these different environments. However, if we delve deeper into this subject we find that humanity, despite its national variations, hitherto have nurtured two distinctive cultures that have evolved side by side over time. By the taxonomy of culture, we mean these two sides of culture. On the one side, we have the national culture. That is groups of people inhabiting a specific location over centuries, who have formed a distinctive identity. In this classification, we do not include arbitrary countries that are forged by colonial powers.

By culture, we mean the culture of a nation. The image that each member of a nation projects about its own identity. The second type is a universal culture. There are two sides, in turn, to a universal culture. It is important we are clear on this point. The matter may be described as the contingency of indiscernible antithetical. What we have here is a unity of negations. On one side we have the domination of irrationalism; totalitarianism, violence, fanaticism, fear, corruption, bigotry, deception and terror. On the other side, we see exactly the opposite.

This opposite side is a culture that is dominated by rationality, liberty, democracy, the work ethic, equal opportunity, responsibility, equality, justice, peace, prosperity and the rule of law. The society here, irrespective of nationality, is open, harmonious, democratic, stable, vibrant, dynamic and inclusive. It makes little difference where a nation is situated. These two aspects of culture cohabit side by side and are shared universally. Be that as it may, these two sides will never coexist in equal measure. One always dominates the other. Here it suffices to say that those cultures that are dominated by theocratic states, fascist and totalitarian states, and colonial geopolitical structures are the complete opposite of cultures that exist and that are dominant in democratic nations. The contemporary extreme representatives of culture in the former category are the colonial theocratic constructions of Pakistan, headed by Punjabi Sunni jihadist army and the colonial theocratic state of Iran, headed by Persian Shiite fundamentalists and their ideological affiliates, Taliban and Hezbollah. Their counterparts, in the extreme left, are the totalitarian regimes of North Korea and the state of Syria led by the Baath party of Syria.

Throughout the history of human societies, we find these two cultural-spheres being in the constant struggle for domination. The most vivid expression of the latter universal mode of culture is dissent and resistance against tyranny, injustice, inequality, and irrationality. The landmark leaps forward for asserting its authority, however, was during the age of enlightenment in Northern Europe. The movement triggered an intellectual trend that profoundly questioned the smothering and long-lasting cultural order. The contest was intense and reflective. It paved the way for the gradual demise of dogmatic absolutism. 
In the course of time, the crosscurrent of enlightenment gained sufficient vigour and was transformed into a force to be reckoned with. The rising cultural mode was one that was rational, humane, democratic, critical and scientific. It cannot be open to doubt that this illuminating upheaval laid the foundations for free, open and modern democratic nations. Effectively, the domination of this cultural sphere in some nations only dates back to post Second World War. It was after the war that we begin to witness the predominance of this cultural-sphere in the true sense of the word, in a number of nations. Initially, it reasserted its dominance in northern Europe, North America, Australia, and New Zealand and followed by other democratic nations.

The enlightenment initiated a far-reaching universal cultural shift. The movement was founded on the principle of superiority of human reason over superstition and dogmas. However, one cannot conduct a rational inquiry unless freedom of thought and expression are granted. No wonder, therefore, that when this prerequisite is duly qualified it brings humankind to the centre of consideration. In brief, the human becomes an end itself. From this, we can ascertain what follows. That is a life of living for oneself and a break from fear of the divine or worldly rulers.

One target of the attack, from the architectures of the enlightenment, was religion. The term religion is a derivation of the Greek word 'religio.' It means 'to return to bondage' [83], a faithful submission to a fixed set of divine rules. Proponents of the age of enlightenment considered any blind belief as irrational. They argued that religion, ideology, belief, and scientific theory are not of equal standing. Predictably, for an upcoming culture to thrive one needed freedom, a democratic, tolerant and inclusive society.

This cultural shift is built on multiple interconnected foundations. The first one was the desire of humanity to improve their living conditions. There was nothing new in this aspiration. It has always been with humanity but precluded from being fully utilized. The search for an ideal society, free of hunger, pain, and disease is a natural human inclination [84]. Living free and leading a happy and healthy life is a desire of every reasonable person, and a powerful motive for human action against repression, hunger and cruelty.

Followers of the Enlightenment questioned the reign of the Inquisition in the Encyclopédie. This was a work initiated by Denis Diderot (1713-84) and Jean Le Rond d' Alembert (1717-83) in 1751. It is to be remembered that ancient wisdom and sacred books were no longer considered the sole source of truth. People began to question the notion of original sin [85]. Many writers; Voltaire, Rousseau, Hume, Morelly, and Helvétius proposed an alternative view. Arguing that human nature is not only wicked but it is compassionate and benevolent. John Locke (1632-1704) described a child's brain as a clean slate, empty of ideas, facts or sins [86]. Jean-Jacques Rousseau (1712-78) professed that people are not wicked by nature. Their environment makes them what they are. In the 'state of nature' people are good and moral [87]. If people are able to reason, they do not need religion. Reason and education are better means to make moral judgments than any outdated religious creeds. By their very nature, religious doctrines are absolute, intolerant and inevitably violent. Gotthold Ephraim Lessing (1729-81), renounced religions as irrational, the cause of fanaticism and against the common good. In his play Nathan the Wise (1779) he advocates tolerance, leniency, and moderation between beliefs and ideas to spread the common good. François-Marie Arouet de Voltaire likened the church to the seat of cruelty and intolerance. In his Letters Concerning the English Nations XII-XV, he states it is not surprising that Francis Bacon, John Locke, and Isaac Newton were from England. It was the culture of freedom and tolerance in England that produced these thinkers.

John Locke (1632-1704) in his Two Treatises of Government, talked about two states, the 'state of nature' and what followed thereafter. In the first period, there is no private property except an individual owning his/her own body. Extrapolating from this, a maxim that nature and freedom are compatible. Nature made human beings free but man-made laws have put human beings in chains. Deducing from this proposition that neither laws nor states are from a divine authority and the essential condition for moral conduct is not the state or religion but liberty. Jean Jacques Rousseau (1712-78) took to heart Locke's basic ideas. Rousseau says people should be master of their own destiny since "man is born free" [88]. Their enslavement came about when "power first made slaves and cowardice hath perpetuated them" [89]. In natural justice, there is no power and "the terms slavery and justice are contradictory and reciprocally exclusive of each other" [90]. Rousseau asserts that "as no man hath any natural authority over the rest of his species, and as power doth not confer right; the basis of all lawful authority is laid in mutual conventions." As humanity and liberty are inseparable "to renounce one's natural liberty, is to renounce one's very being as a man; it is to renounce not only the rights but even the duties of humanity ... for to deprive us of the liberty of the will, is to take away all morality from our actions" [91].

Most advocates of the enlightenment asked for free speech and the eradication of dictatorships. Charles-Louis de Secondat, Baron de la Brède et de Montesquieu (1689-1755) and François-Marie Arouet de Voltaire (1694-1778), argued to reason effectively we need liberty to express our thoughts freely. The equalitarian liberals in England and America went a step further and called for freedom of association and assembly to make sure freedom of speech is fully assured.

One of the main concerns of the inventors of the age of enlightenment was law. Law used to be customary, vague and biased and arbitrary. Montesquieu work, The Spirit of 
the Laws, questioned that legal system. The book explored the despotic systems and proposed a legal system that is impartial. A system where each individual is equal under the law and the state is answerable to the same law. He also proposed a system where the power of the state is divided into different organs of the government. Dispersing the power of government into the executive, legislative and judicial branches of the state. Or else, there will be no freedom.

Cesare Beccaria (1738-94) expressed his anxieties about torture and capital punishment. In his book, On Crimes and Punishments (1764), he described these methods as 'cold cruelty.' In the first place, Beccaria pointed out, to get rid of such malaise, first we must apply the fundamental principle of "in the eye of the law, every man is innocent, whose crime has not been proved" [92]. Secondly, the accused should be presumed innocent before being proved guilty. Thirdly, the punishment should be proportional to the severity of the crime [93].

Another conviction of the age was a belief in human progress. Medieval attitudes toward human prospect were bleak. Human fate was doomed. In contrast, the forerunners of enlightenment had an outlook that was more promising and inevitable. Marquis de Condorcet (1743-94) in the Sketch for a Historical Picture of Progress of the Human Mind, 1794, identified ten stages in human progress. The last stage is the Tenth Epoch. This is the ultimate destination when rationalism and science will prevail. By substituting reason instead of superstition people will discover all laws, natural and moral laws, and apply them for a common well-being. In the perfect society - "the destruction of inequality between different nations; the progress of equality in one and the same nation; and lastly, the real improvement of man" will be the order of time [94].

Morelly published Code of Nature, in 1755, where he defined the outline of communism. His idea of communism rests chiefly on his reliance on the power of science and human benevolence. Given that human beings are good then it is their conditions that make them bad. It is "the circumstances of life in this world" that "inevitably predispose [them] to perverseness." So what is needed is the provision of a good environment and scientific education to create an ideal society [95].

Alongside the age of enlightenment, we had the rise of European Empires. Johann Gottfried von Herder Her (1744-1803) opposed imperial conquests. Forceful subjugation of any nation, he insisted, is unjust and contrary to the principle of equality. He dedicated the central theme of his book, Outlines of a Philosophy of the History of Man (1784) in defence of the equality of nations and cultures. Stressing that colonialism is wrong. For the reason that by taking over one's nation "you deprive them of everything" [96].

One superseding theme that defines the age is faith in humanity. This conviction was crystallised most in
Immanuel Kant (1724-1804) writings. Kant described the age as the beginning of the "age of enlightening." In his, The Critique of Pure Reason (1781), he specified the conditions for advancing to the next stage as the effective application of liberty and reason. Arguing that one cannot reason effectively unless one is free. Kant says that "the public use of one's reason must always be free, and that only can bring about enlightening among men" [97]. Similarly, morality is incapacitated without rationality. Making right moral judgments requires a rational faculty but if the rational agency is barred from free reasoning the judgment would be incomplete. Freedom to reason and judgment work well when society is free.

Besides the many scientific discoveries and innovations that changed the way people thought, the methodology of research itself came under the scrutiny of critical thinkers of the age. In this field, the work of English jurist Francis Bacon (1561-1626) has left a lasting legacy. Bacon launched his criticism of scholastic and deific literature, both the sacred and the secular texts. Denouncing them as hollow. A venture that was not just radical but very risky at the time. His distrust of conventional methodology was a major step indenting the self-image of those in charge. It certainly unlocked the gate to empirical methods, pursuing truth in careful observation of reality, events, and nature [98].

One of those who embraced Bacon's method was Isaac Newton (1643-1727). Newton's seminal contributions and discoveries on the laws of motion, in optics and mechanics, discredited the standard understanding of the cosmos and planetary motion. Modern chemistry too heavily relied on the same methodology. Initiated by the French Chemist, Antoine Laurent Lavoisier (1743-94). Lavoisier termed modern chemistry as an experimental science, placing nature as the source of truth and experiment, the method of exposing the truth. Nature, he remarked, is "a vast chemical laboratory ... We must trust in nothing but facts. These are presented to us by Nature and cannot deceive. We ought in every instance to submit our reasoning to the test of experiment" [99].

The English naturalist, Charles Darwin (1809-82) applied the same method. In his scientific mission, Darwin joined the second voyage of HMS Beagle in 1831. The mission lasted about five years. The ship circumnavigated the globe and Darwin observed and recorded the conditions and places that various animals cohabited. These exhaustive observations and gathering of facts were the precursor to his celebrated theory of evolution and natural selection. A theory that he expounded in his great work, $O n$ the Origin of Species, 1859.

All these intellectual endeavours, findings, and upheavals cultivated the formation of a new cultural order. This order has subsequently shaped the dominant culture of democratic nations. This order regards human beings as an end, not a means to serve another end. The essence of this culture is humanism, rationalism, liberty, justice, equality, 
progress and responsibility. Its outlook towards life is realistically conserved in optimism that confides in the power of human reason, personal liberty, and moral judgment. This is the side of the universal culture that is open and critical that values freedom of thought and a democratic rule of law.

\section{The Parts and the Whole}

Indeed, the multiple definitions of culture given only cover some aspects of culture. Each definition or combination of all jointly given so far falls short of what culture actually is. The prevailing narratives receive culture as a part of a whole. The position of the part varies from being inconsequential to partially relevant. Either way, it is viewed as only a part of the whole. Let us elucidate the misgivings that rest at the heart of the matter with a brief account of the relationship between the parts and the whole. If we take any human society, it would not be unreasonable to suppose that it is the admixture of many parts. Understandably, the parts vary in size, scope, and significance. Assume, for the sake of an argument that society is a jigsaw. The constituents of this jigsaw are economy, language, science and technology, law and order, politics, institutions, art and music, social and moral codes and values, religion, language and so on. The fact is we can fit the parts of the jigsaw together to create a whole. The question is what binds the parts in the whole? This being the case, what is the whole that consolidates all the parts and by what means do these parts combine together.

By the whole, we mean all that belong to the jigsaw. It is the totality of its contents. This includes everything; objects, attributes, and their relations. It is hard to imagine a human society without this string of connectives that bridges the parts to create the entire piece. One may contest the analogy but cannot disregard the fact that there must be something in the fabric of any human society that binds the miscellaneous parts into a unified whole. Something that is neither the parts nor the whole. That something is culture and the function that it assumes in adjoining the fibre of the texture of the society is the essence of culture.

A similar argument can be advanced by adopting a different analogy. Let us equate human society to the cosmos. Furthermore, we take the universe as our point of reference. It is conceivable to infer that the cosmos is comprised of all matters, time, space and their contents. All planets, stars, galaxies are within the frontier of the universe. Cosmos is the whole world, the totality that all contents of intergalactic space from subatomic particles to vast galaxies, all matter, and energy. We have the entire celestial cosmos in mind.

Human society is merely a speck in this gigantic whole. Nevertheless, a human society, relatively speaking is a whole in itself. On the balance of reflection, this is a fundamental stand to start our argument from. That can be any given human society - whatever takes place within the boundary of human society. It means the building blocks of each human society; the economy, the institutions, rules and regulations, customs and habits, beliefs, ideologies and religion, science and technology, political orders and systems, art and music, language and so on. The question is what connects these parts. What force binds them together? What holds the entire society together?

To fully comprehend our argument we must turn back to our analogy of the universe. We have said that the universe consists of an infinite number of parts. The question is what force binds different parts of the universe together, including the subatomic structure of the universe. How the elementary particles are joined to form the universe. There must be something that holds the building blocks of the universe together into a unified whole. What is this cosmic force that binds the entire universe together?

The answer to this question was postulated first by the English physicist and mathematician Isaac Newton (1643-1727). In his generally acclaimed book, Mathematical Principles of Natural Philosophy (1687, Newton developed his ground-breaking law of gravitation. The law states that there is a force between all objects in the universe. This force attracts and pulls the objects, which is directly proportional to the product of their masses and inversely proportional to the square of the distance between them. Our reference to this force and law is neither to confirm nor to refute the theory. It may or may not be applicable everywhere in the universe. That is not our concern here. For the purpose of our study, this reference is made to demonstrate the point that where there are parts that produce a whole then there must be something that binds these parts to make the whole. In the case of the universe, Newton argued that this force is the universal law of gravitation.

Let us look at a couple of more analogies. The same could be said of the circulation of blood in a living organism. The distribution of blood to different parts of the body is carried out through the vascular system. This is done by means of three main types of vessels that make up the vascular system. These are arteries and arterioles, capillaries and lastly veins and venules. All parts are fused in forming the vascular system, the whole. What is true of the vascular system is also true of DNA, the deoxyribonucleic acid that holds each individual's genetic information. The living organisms, in this case, is the whole, which is diverse and complex. The DNA makes an individual is what it is and distinguishes one individual from another but at the same time holds them in one totality (as a human race). The same thing can be said about the Darwinian Theory of evolution, the theory of the survival of the fittest. That is those species that are suited best to their environment will survive and proliferate and those species that cannot adapt to the changing environment will become extinct. This principle applies to all living species as a whole. 
Culture in human societies assumes a similar binding function. It is an all-inclusive adhesive that ties the fabric of the whole society together. This consists of all aspects of society including beliefs, mores, customs, values and practices, signs, symbols, text, language, oral and written inheritance, music, literature, poetry, dance, drama, and visual art. It also ties other aspects of society such as the economy; law and order, ethics, science and technology, institutions, ideology, religion, politics and so on. Culture is that invisible string that pierces through all parts and connects every part to the whole.

\section{Conclusions}

The paradox about the concept of culture is that all disciplines, scientific or otherwise, use the term in their narratives. But at the same time, the meaning of culture is as diverse as the number of authors who have tried to define it. In this study, we have narrowed the range of our inquiry to social science, most specifically to economics.

The disagreement on this issue is most evident among economists. Every economist admits the reality of culture. Yet, some exclude it from the economy. This trend is most palpable among the neoclassical school. Two influences have been critical in this regard. First of all their adherence to Bentham's utilitarian philosophy. Another factor has been the 'mathematisation' of economics. There is nothing unusual about the application of mathematical tools in enhancing our understanding of economics. It gets problematic, however, when the entire economics is curtailed to mathematical and geometric language. The mathematical instruction becomes an end in itself. Anything that is not expressed in numeric terms is discarded as unscientific.

Those economists who find a place for culture also widely disagree on its meaning. In their evaluation culture is only a secondary factor, a subordinate to either the economy; politics, law, technology, ideas, religion or a combination of these fundamentals. One thing that we can be sure of is a human society cannot be formed without culture. That is to say, one isolated individual cannot create a culture. A culture is constructed in a human society because humans are social beings. The origin of culture is in the necessity of human beings to have a social life. The creation of human culture is a formal necessity.

Each constituent of a culture is not necessarily indispensable. On the contrary, it may be at variance to the vitality and its future prospects but this is not a sufficient reason to decimate that particular culture completely. The lack of sophistication or the deficiency in some elements of a culture is not grounds for the rejection of a culture in its entirety. The logical conclusion of this line of attack is to inevitably brand the bearer of that culture, intentionally or otherwise, as savages and uncultivated. Once this premise is established then they can be forced to adopt a colonial culture. A related dimension to this fallacy is the idea of restricting culture to countries rather than to nations. A country can be a work of colonial construction, forged by dissecting nations illegally and by force.

A culture is formed instantaneously with the formation of a society. In the absence of culture the countless specialization of employment, compounded with cohabitation of diverse and opposite interests would not materialize. Neither would it be possible to make sense of true and false, and right and wrong dimensions of our reality. Our visible and invisible contracts, either way, take place in the context of a given society. In view of this human beings by necessity form their culture to live in a society and to define their common identity and shared goals.

Culture in its totality is invisible. That is why it cannot be defined in a strict mathematical analogue. One cannot see its beginning and its end. It corresponds to multiple layers of bubbles that cover everything in a society and connect every aspect of that society. In the confinement of this invisible sphere and by means of these invisible strings our thoughts, feelings, values, obligations, motives, actions are formed and realized. Culture can only be understood in terms of its relation to society and in its connection to different parts of society.

Subject to these qualifications, we can distinguish two complementary sides to each culture. One is its national component and the other is its universal component. The national component of a culture is what we characterize as the multiple layers of bubbles that cover everything in society and the invisible strings that connect every aspect of that society within a given nation. Be that as it may, the universal components of culture are not unique to each nation. They apply to all individuals and all nations.

The universal ethos of a culture is founded on universal principles. At its core stands the cardinal principle of the moral supremacy of each person as an end and not as a means to serve an end. On this imperative code of conduct, all individuals are held to be equal to one another. This cultural ethos stands for the power of reason and in opposition to any form of dogma and bigotry. It treats each individual equally and entitles each to all rights, protections, and freedoms under the law in all spheres of society, in civil, economic, education, social, and political rights. Among the sovereign principles of this universal ethos are the application and true implementation of democracy; personal liberty, freedom of thought, beliefs, speech, fairness, equal opportunity, peace, security, and tolerance. By its very nature, the universal ethos is inclusive and pays due respect to human rights, civil and political rights, environment, the rights and welfare of other living species too. On the opposite side is a culture of irrationalism, violence, intolerance, repression, theocracy, despotism, tyranny, dictatorship, censorship, deceit, and bigotry.

An economy comprises one part of the culture. There is 
not any economic interaction and relation that is not discharged in a prearranged trajectory of a given culture. Contrary to conventional wisdom in economics culture is neither totally irrelevant nor should it be regarded as a secondary element in society. Far from it, culture is the thing that accommodates and connects all the diverse parts of a society into an organised and workable whole. Without this unifying vessel and thread a society would not exist nor would it continue to function effectively. The realization of this fact will evidently result in some profound implications to our understanding of the society in general and the economy in particular. Economic advances, when other factors remain the same, would have a greater impact when there is a culture that is open to reason and criticism and that upholds humane and democratic values. Such cultures create vibrant environments that are dynamic and adaptable to the ever-changing world. They are also in a superior position to better cope with new challenges and opportunities.

\section{REFERENCES}

[1] The UN (27c/INF.11 - 8 October 1993).

[2] Throsby D. (2001) Economics and Culture, Cambridge University Press, Cambridge, p. xiii.

[3] Throsby D. (2001) Economics and Culture, Cambridge University Press, Cambridge, p. 3.

[4] Fuhrer U. (2004) Cultivating Minds: Identity as Meaning Making Practice, Routledge, p. 39.

[5] Lambert G. (2004) The Return of the Baroque in Modern Culture, Continuum, London, p. 102.

[6] Beugelsdijk S. and Maseland R. (2011) Culture in Economics, Cambridge University Press, Cambridge, p. 3.

[7] Oswald W. (1907) The Modern Theory of Energetics, The Mononist, No. 17, p. 510.

[8] Herskovits M. J. (1948) Man and his Works, A. Knopf, New York, p. 17.

[9] Inglehart R. (1990) Culture Shift in Advanced Industrial Society, Princeton University Press, Princeton, p. 18.

[10] [10] Kroeber A. A. and Kluckhohn C. (1952) Culture: A Critical Review of Concepts and Definitions, Vintage Books, New York, p. 85.

[11] Tylor E. B. (1924) Primitive Culture, vol. 2, $7^{\text {th }}$ ed., Brentano's, New York, p. 1.

[12] Nafziger J. A.R., Paterson R. K. and Rentln A. D. (2010) Cultural Law, Cambridge University Press, Cambridge, p. 126.

[13] Malinowsk B. (1944) A Scientific Theory of Culture and other Essays, UNC Press, Chapel Hill, p. 40.

[14] Geerz C. (1973) Religion as a Cultural System, The
Interpretation of Cultures, Basic Books, Inc., New York, p. 89.

[15] Beugelsdijk S. and Maseland R. (2011) Culture in Economics, Cambridge University Press, Cambridge, p. 6.

[16] Hofstede G. (1980) Culture's Consequences, Sage Publications, London, p. 25.

[17] Wallis W.D. (1930) Culture and Progress, Whittlesey House, New York, p. 9.

[18] Benedict R. (2005) Pattern of Culture, A Mariner Book, Boston, p. 16.

[19] DiMaggio P. (1994) Culture and Economy, in (ed.) N.J. Smelser and R. Swedberg, The Handbook of Economic Sociology, Princeton University Press, Princeton, p. 29.

[20] Linton R. (1945) The Cultural Background of Personality, Appleton-Century-Crofts, New York, p. 30.

[21] Williams R. (1961) The Long Revolution, Chatto and Windus, London, p. 41.

[22] Johnson A. W. (1988) Free trade and cultural industries, in (ed.) M. Gold and D. Leyton-Brown, Trade-Offs on Free Trade - The Canada-U.S. Free Trade Agreement, Carswell, Toronto, p. 350 .

[23] Garnham N. (1990) Capitalism and Communication, Sage, p. 155.

[24] Robertson R. (1992) Globalization - Social Theory and Global Culture, Sage, London, p. 40.

[25] Friedman J. (1994) Cultural Identity and Global Process, Sage, London, p. 67.

[26] Tylor E. B. (1958) The Origins of Culture, Harper and Row, New York, p. 1.

[27] Kluckhohn C. (1962) Culture and Behavior, The Free Press of Glencoe, New York, p. 73.

[28] Mead M. (1955) Cultural Patterns and Technical Change, UNESCO, Paris, pp. 9-10.

[29] Frow J. (1995) Cultural Studies and Cultural Value, Clarendon Press, New York, p. 3.

[30] Lederach J. P. (1995) Preparing for Peace, Syracuse University Press, Syracuse, p. 9.

[31] Eagleton T. (2000) The Idea of Culture, Blackwell, Malden, p. 34.

[32] Matarasso F. (2001) Culture, Economics and Development, in (ed.) F. Matarasso, Recognising Culture, Comedia, London, p. 3.

[33] Keesing F. (1964) Cultural Anthropology, Rinehart and Winston, New York, p. 18.

[34] Petrakis P. E. (2014) Culture, Growth and Economic Policy, Springer, Athens, p. 30.

[35] Smith A. (1976) The Theory of Moral Sentiments, Clarendon Press, Oxford, p. 162.

[36] Smith A. (2009) An Inquiry into the Nature and Causes of the Wealth of Nations. The Five Foot Self of Classics vol. X, 
(ed.) C.J. Bullock, Cosimoclassic, New York, p. 541.

[37] Mill J. S. (1970) Principles of Political Economy, Penguin Books, London, p. 350.

[38] Bentham J. (2007) An Introduction to the Principles of Morals and Legislation, Dover Publications, INC., Mineola, p. 1.

[39] Bentham J. (2007) An Introduction to the Principles of Morals and Legislation, Dover Publications, INC., Mineola, p. 3 - italics in original.

[40] Chirot D. (1994) Modern Tyrants, Princeton University Press, Princeton, p. 51.

[41] Jevons W. S. (1970) The Theory of Political Economy. (ed.) R. D. Collison Black, Penguin Books, Harmondsworth, pp. 77 and 101 - italics in original.

[42] Jevons W. S. (1970) The Theory of Political Economy. (ed.) R. D. Collison Black, Penguin Books, Harmondsworth, p. 101 - italics in original.

[43] Jevons W. S. (1970) The Theory of Political Economy. (ed.) R. D. Collison Black, Penguin Books, Harmondsworth, p. 78.

[44] Silverman P. (1990) The Cameralist Roots of Menger's Achievement, in (ed.) Bruce J. Caldwell, Carl Menger and his Legacy in Economics, Duke University Press, Durham, pp. 90-912.

[45] [45] Marx K. (1983) Capital. vol. I, Lawrence and Wishart, London, pp. 78-79.

[46] Zouboulakis M. S. (2014) The Variety of Economic Rationality, Routledge, p. 27 - italics in original.

[47] Lanreth H. and Colander D. C. (1994) History of Economic Thought. $3^{\text {rd }}$ ed., Houghton Mifflin Company, Boston, pp. 219-20.

[48] O' Boyle B. and MacDonough T. (2016) The State of Nature and Natural States, in (ed.) J. Morgan, What is Neoclassical Economics? Debating the origins, Meaning and Significance, Routledge, Abingdon, p. 215.

[49] Mirowski P. (1999) More Heat than Light, Cambridge University Press, Cambridge, p. 3.

[50] Petrakis P. E. (2014) Culture, Growth and Economic Policy, Springer, Athens, p. 31.

[51] Petrakis P. E. (2014) Culture, Growth and Economic Policy, Springer, Athens, p. 33.

[52] Lanreth H. and Colander D. C. (1994) History of Economic Thought. $3^{\text {rd }}$ ed., Houghton Mifflin Company, Boston, p. 331.

[53] Lanreth H. and Colander D. C. (1994) History of Economic Thought. $3^{\text {rd }}$ ed., Houghton Mifflin Company, Boston, p. 332 .

[54] Veblen T. (1932) The Place of Science in Modern Civilization and Other Essays, Viking Press INC, New York, pp. 241-42.

[55] Veblen T. (1932) The Place of Science in Modern Civilization and Other Essays, Viking Press INC, New York, pp. 242-43.
[56] Gonce R. A. (1971) John R. Commons's Legal Economic Theory, Journal of Economic Issues. vol. 5, no. 3, p. 80.

[57] Lanreth H. and Colander D. C. (1994) History of Economic Thought. $3^{\text {rd }}$ ed., Houghton Mifflin Company, Boston, p.348.

[58] Commons J. R. (1934) Institutional Economics, Macmillan, New York, p. 73 - italics in original.

[59] Machlup F. (1991) Economic Semantics. $2^{\text {nd }}$ ed., Transaction Publishers, New Brunswick, p. 29.

[60] Galbraith J. K. (1991) A History of Economics, Penguin Books, London, p. 282.

[61] Myrdal G. (1955) The Political Element in the Development of Economic Theory, Harvard University Press, Cambridge, pp. vii-viii.

[62] Myrdal G. (1968) Asian Drama. vol. I, Pantheon, New York, p. $x$.

[63] Max-Neef M. A. (1991) Human Scale Development, The Apex Press, New York, pp. 29-33.

[64] Haralambos M. (1990) Sociology: Themes and Perspectives, $3^{\text {rd }}$ ed., Unwin Hyman, London, p. 3.

[65] Haralambos M. (1990) Sociology: Themes and Perspectives, $3^{\text {rd }}$ ed., Unwin Hyman, London, p. 10.

[66] Durkheim E. (1950) The Rules of Sociological Method. $8^{\text {th }}$ ed., translated by Sarah A. Solovay and John H. Mueller, The Free Press, Collier - Macmillan Limited, New York, p. 3.

[67] Durkheim E. (1964) The Division of Labour in Society, Free Press, New York, p. 203.

[68] Swedberg R. (2003) Principles of Economic Sociology, Princeton University Press, New Jersey, p. 226.

[69] Sica A. (1990) Weber, Irrationality, and Social Order. University of California Press, Berkeley, p. 155 - italics in original.

[70] Morrison K. (2006) Marx, Durkheim, Weber: Formations of Modern Social Thought, $2^{\text {nd }}$ ed., SAGE Publication Ltd, London, p. 354.

[71] Weber M. (1999) Max Weber Essays in Economic Sociology, edited by R. Swedberg, Princeton University Press, New Jersey, p. 19.

[72] Weber M. (2011) Methodology of Social Sciences. Translated by Edward A. Shils and Henry A. Finch, Free Press of Glencoe, New Jersey, p. 76.

[73] Marx K. (1971) A Contribution to the Critique of Political Economy, Lawrence and Wishart, London, pp. 2021.

[74] Marx K. (1973) Grundrisse. Translated by M. Nicolaus, Pengin Books, Harmondsworth, p. 265.

[75] Marx K. and Engels F. (1968) Manifesto of the Communist Party. Foreign Languages Press, Peking, p. 30.

[76] Petrakis P. E. (2014) Culture, Growth and Economic Policy, Springer, Athens, p. 31.

[77] Hobbes T. (1962) Leviathan, edited by J. Plamenatz, 
Fountain Books, Glasgow, p. 143.

[78] Evrigenis I. D. (2009) Hobbes's Clockwork: The State of Nature and Machiavelli's return to the Beginnings of Cities, in (ed.) S. R. Krause and M. A. McGrail, The Arts of RuleEssays in Honour of Harvey C. Mansfield, Lexinton Books, Lanham, p. 191.

[79] Aristotle (1970) The Politics. Translated by T. A. Sinclair, Penguin Books, Harmondsworth, p. 28.

[80] Canning J. P. (1980) A Fourteenth-Century Contribution to the Theory of Citizenship, edited by B. Tierney and P. Linehan, Authority and Power, Cambridge University Press, pp. 204-205.

[81] [81] Aristotle (1970) The Politics. Translated by T. A. Sinclair, Penguin Books, Harmondsworth, p. 29.

[82] Cooley C. H. (1902) Human Nature and the Social Order, Charles Scribner's Sons, New York, pp. 147-49.

[83] Bates L. (2009) The New Economic Disorder, Excel books, Florida, p. 42.

[84] Karimzadi S. (2015) Dialectic of Regressive Errors, Humgaam Press, London, p. 16.

[85] Armstrong K. (1999) A History of God, Vintage, London, pp. $144-45$

[86] Locke J. (1964) An Essay Concerning Human Understanding, edited by A. D. Woozley, The Fontana Library, London, pp. 83-84.

[87] MacIntyre A. (1998) A Short History of Ethics. $2^{\text {nd }}$ ed., Routledge, London, pp. 183-84.

[88] Rousseau J. J. (1764) A Treaties on the Social Compact: or the Principles of Political Law, Printed for T. Becket and P. A. de Hondt, p. 3.

[89] Rousseau J. J. (1764) A Treaties on the Social Compact: or the Principles of Political Law, Printed for T. Becket and P. A. de Hondt, p. 6.

[90] Rousseau J. J. (1764) A Treaties on the Social Compact: or the Principles of Political Law, Printed for T. Becket and P. A. de Hondt, p. 16.

[91] Rousseau J. J. (1764) A Treaties on the Social Compact: or the Principles of Political Law, Printed for T. Becket and P. A. de Hondt, p.12.

[92] Beccaria C. B. D. (1813) An Essay on Crimes and Punishment, Printed for J. Almon, p. 74.

[93] Beccaria C. B. D. (1813) An Essay on Crimes and Punishment, Printed for J. Almon, p. 37.

[94] Condorcet A. N. (2009) Outlines of an Historical View of the Progress of Human Mind, G. Langer, Chicago, p. 353.

[95] Fried A. and Sanders R. (1964) Socialist Thought: A Documentary History, Columbia University Press, New York, pp. 18-31.

[96] Herder J.G. (1803) Outlines of a Philosophy of History of Man. vol. II: Printed by Luke Hanfard, p. 303.

[97] Kant E. (1798) Essays and Treatises on Moral, Political, and Various Philosophical Subjects. vol. 1, William
Richardson, London, p. 6.

[98] Boumans M. and Davis J. B. (2016) Economic Methodology, $2^{\text {nd }}$ ed., Palgrave, London, p. 153.

[99] Jaffe B. (1960) Crucibles: The History of Chemistry, Premier Books, Fawcett World Library, New York, p. 70. 